\title{
WHAT DRIVES CITY BRAND ATTRACTIVENESS? AN EMPIRICAL STUDY ON SOME PROVINCES IN INDONESIA
}

\author{
Pasaman SILABAN* \\ University of HKBP Nommensen, Faculty of Economics and Business, North Sumatera, Indonesia, e-mail: pasamansilaban@yahoo.co.id
}

\begin{abstract}
Citation: Silaban, P. (2021). WHAT DRIVES CITY BRAND ATTRACTIVENESS? AN EMPIRICAL STUDY ON SOME PROVINCES IN INDONESIA. GeoJournal of Tourism and Geosites, 38(4), 1299-1308. https://doi.org/10.30892/gtg.38438-772
\end{abstract}

\begin{abstract}
Current study is aiming to investigate the key determinant factors of city attractiveness. Research background was triggered by, firstly, the lack of literature focused on this phenomenon. Secondly, the concern of people to live in environmentally friendly place and the local plan to complete city management in order to increase economics performance and international competitiveness by using visibilities and economics benefit globally. This research took sampling with specific target (600 respondents) from local potential talents, such as young entrepreneurship, international business, high educated persons with age range 25 until 45 years old. A ten likert scale is used to evaluate city brand which is considered as a key factor to influence city attractiveness. A structural equation modeling is deployed to analyze the city attractiveness driven. Those driven factors such as environmental outlook, responsive social service, tourism and cultural tangible, education and job opportunity, safety and health, international level and city attractiveness performance. Statistical outputs demonstrated that all hypotheses (H1 until H5) have shown significant antecedents of city attractiveness. H6 stated that international level is insignificant as a driver for city attractiveness performance.
\end{abstract}

Key words: environmental outlook, responsive social service, tourism and cultural tangible, education and job opportunity, safety and health, international level, city attractiveness performance

$* * * * * *$

\section{INTRODUCTION}

It has been proven that the interest of researcher and academicians on place marketing and city attributes existed in the literatures, some of them are worth to mention (Kavaratzis, 2005) studied on city marketing place, city intention on heritage (Chen and Chen, 2010), residents as stakeholders (Garrod and Fyall, 2012), place brand dynamics (Kavaratzis and Hatch, 2013), brand destination assessment (Kladou and Kehagias, 2014), attribute on city branding attractiveness (De Noni and Orsi, 2014), city brand orientation (Ahn et al., 2015); new place bonding (Cheng and Kuo, 2015); brand equity destination (Gómez et al., 2015); city personality destination (Hultman et al., 2015); city identity (Zhou and Liu, 2014); city cultural heritage (Barrère, 2016); customer-based brand equity (Bose, et al., 2016); city attribute attractiveness (Farida and Ardyan, 2016); social media marketing (Godey et al., 2016); cross validation of tourist destination (Iniesta-Bonillo and Sánchez-Fernández, 2016); heritage franchising (Adie, 2017); city brand image (Ansary and Nik Hashim, 2017); key factors of residents subjective (Chi et al., 2017); hierarchy of destination (Herrero and San Martín, 2017); city destination image (Kani and Aziz, 2017); branding space (Gatrell et al., 2018); country image and destination (Chaulagain et al., 2019), and the driver of city image(Coelho and Bairrada, 2020).

A study that investigate the benefits gained from population and facilities which covered the accessibility (Escobar and Cardona, 2020), sophisticated in cultural tourism (De Man, 2020), antecedent of city brand attractiveness (Miftahuddin and Hermanto, 2021); correlation of culture and surrounding (Szente and Osiako, 2021), cultural heritage (Ilieș et al., 2020), tourism village development (Istiqomah and Adawiyah, 2020), divulging of tourism cite (Wibowo and Santosa, 2021), innovated activity and tourism (Gorochnaya and Mikhaylov, 2021), cultural based-design (Anusorntharangkul and Rugwongwan, 2021). Through the various topics mentioned above, this study tried to review some place and branding management that have been playing massive role in influencing city competitiveness as well as city attractiveness. Many cities competed to drag attention of investors, companies, tourisms, new citizen or even job seekers who fulfill the requirements which are so called as talents (Zenker and Knubben, 2019) and a study which emphasized on the development and city planning competitive aspect (Kavaratzis and Ashworth, 2006). Even though the evidences proved that city attractiveness and competitiveness depended on effective definition, communication and city brand management (Ashworth and Kavaratzis, 2007), destination quality has been highlighted as key determinant factor to affect city competitiveness as well as attractiveness and talents (Darchen and Tremblay, 2010).

Citizens and potentials residents' vision on the city brand attitude is crucial related with specific city to determine city attractiveness capacity. There were several city attributes which affected city brand attitude (Merrilees et al., 2009) and included international features, economics, social, health, security, education, environment, tourism as well as culture. Besides, city branding is needed to be involved and combined some groups interest, stakeholders such as citizens (Braun and Kalandides, 2013), new places to live, tourism (De Carlo and Canali, 2009), Talents (Darchen and Tremblay, 2010),

\footnotetext{
* Corresponding author
} 
corporate, entrepreneurs and investors (Yusuf and Nabeshima, 2005). Place marketing should be integrated with different stakeholders to create perception and positive global and local attitude (Fetscherin and Dinnie, 2010). Place quality is depending on city location in some people thoughts, those opinions could be affected by the perspectives and different interest from various groups (Zenker and Knubben, 2019). City attributes could be mixed, in order to drag the talents and creative to be able to increase the general city attractiveness for the investor and companies (Zenker and Kalandides, 2009). In this case, the skillful persons could contribute to create value for a city, leverage reputation, support city internationalization. In the current study, the talents perceptions were analyzed in relationship with brand building process. Yet, in accordance with (Zenker and Kalandides, 2009) stated that, even though the competitions were considered to be creative class, it could be determined as a global challenge, the most success strategy to handle the national sub-group was cultural based. This research was focused on local talents who live nearby and make a visit regularly.

Current study would like to investigate the key determinant factors of city attractiveness. Firstly, the lack of literature focused on this phenomenon (Kavaratzis and Ashworth, 2006), secondly, the concern of people to live in harmony and the local plan to complete city management in order to increase economics performance and international competitiveness by using visibilities and economics benefit globally. The goal of current research is to analyze city dimensions which affect life quality, and in turn, it is expected to influence city capacity to attract talents, such as young entrepreneurship, international business, and high educated persons. Thus, finally this research aims to determine the practical implication of place and city brand marketing locally and globally. This research conducted in sequences, the first part is to discuss the place marketing approach to measure the perception of place and city brand. Secondly, this study focuses on city attributes which affect the life quality and city attractiveness that trigger talents new residents. Furthermore, defining extended city brand index, based on the six main antecedents which are affecting city brand attractiveness used to evaluate city attractiveness. The next part, sampling, questionnaires and variables and its indicators are defined and explained. The last part of this study, discusses the findings and practical implication of place marketing.

\section{THEORETICAL REVIEWS AND HYPOTHESES DEVELOPMENT}

It is generally believed that place branding is considered as a new topics discussed in the field of academic study. This topic is appeared due to the pace promotion that progressively developed to become the approach on working frame in strategic planning, which is applied in place branding (Kotler and Bowen, 2003). Recording the real changes of promotion on branding and marketing (Kavaratzis and Hatch, 2013). Specifically, the authors summarized some important factors that appeared in the topics such as original place, nationality, culture and entertainments, place of destination or city branding, brand image have become the potential aspects of place marketing and, as its consequences, the development of studies and practices within brand image. Recently, some different places management and approaches on some brand have been identified and discussed. These included related network branding, communicative city image, destination branding model, process on destination branding, managed city branding, strategic of place branding management model.

Each model tried to develop the branding-based process on evaluation on place brand, brand infrastructure relationship, the involvement of stakeholders, place brand articulation as well as brand communication. Regardless, all models is perfect and widely adopted, this is to consider that the necessity of place marketing as crucial assets for city development and attractiveness (Kavaratzis and Ashworth, 2006). Thus, to increase the relevancy and the competitiveness of city brand image which is supported by the city brand development and its popularity such as City Brands Index or Saffron European City Brand Barometer (Hildreth, 2011). For the new brand model, the similarity among companies and city branding had been outlined (Merrilees and Abimbola, 2012) throughout the widen of stakeholders perspectives from companies to city level. This is to show that city brand image was affected by identity ad conflicts of interest among different stakeholders (Gopalan and Narayan, 2010). To claim that this is crucial to direct local decision maker to set main goals as well as strategic plans to leverage city brand perception based the goals settled. To conduct this, comprehensive value, needs, preferences and behavior were chosen from the various targeted groups (Zenker and Kalandides, 2009).

Theoretically, it is claimed that stakeholders have the different brand image perception (Fitchett, 2005) which have been empirical validated in the new study (Merrilees and Abimbola, 2012). Based on stakeholder's perception and focus enlargement during the last years on city capacity to attract and sustain talents, this study refers to the model that could be able to evaluate city attribute that affects city image which related with talents. This model is expected to deliver the beginning data concern on brand perception or image, which needed to define and apply integrated planning.

\section{Talents and Potential Residents}

Every city needs to invest continuously in human resources to be competitive. (Michaels and Handfield, 2001) discussed about competition on talent among cities and regional. The author showed that the workers in a location could support local economic development. Thus, the model of HRM focused on the importance of high educated and professional workers (Florida, 2008) referred to what is called creative class and shared opinion that is playing important role to increase city social economics development. Based on the economic development external model, it is stated that the bigger number of residents in a place, the higher the total of existed externality. The capability of a place to specialize and export is depending on talents and the integration with them and the interaction in local economics (Markusen, 2004). Furthermore, Cortright and Coletta, 2006 described the important role of individual with high education in a city. A study which described more details on how high concentration of young talents made a metropolitan more interesting, the young resources of capital and educated could be a driving factors for a change or city economics regeneration (Porter, 2011). Talents individual with higher education and professional skill are tend to have location that support their productivity, and prefer the accommodation such as other talents 
who could able to motivate and knowledge sharing and transfer (Lawton and Glasson, 2005) .The success of city brand strategy and brand communication was important to promote positive perception regarding on city attributed. If a non-resident individual has an attitude to support city brand, they will tend to move to the city (Fiocca and Gavinelli, 2011).

\section{Measurement of City Attractiveness.}

Based on literatures reviewed, there were two branding measurements adopted from corporate branding which mostly deployed. Brand equity approach based corporate is the top down approach of measurement which used the information of total corporate performances. The similar approach could be also applied for specific brand of a country by estimating how good a country's performance (Fetscherin and Dinnie, 2010) in the case of export, tourism, foreign investor, immigration and government environmental. At the other hand, brand equity approach based customers is the bottom-up approach (Atilgan et al., 2005). This approach is generally focused on learning about the customers vision on a brand by collecting primary survey data (Fetscherin and Dinnie, 2010). Some countries brand index has been applied this prospect. Zeugner and Diamantopoulos (2008) further stated that country brand equity is affected by a country image perception. Thus, customer based approach seemingly is better to evaluate actual capacity to attract qualified potential residents. This study is not designed to define the new city competitive index but to explore related city attractiveness with perception of city life quality which affects city capacity for talents and potential residents. Based on literatures reviews, there are 9 city attributes identified to propose a multidimensional approach.

\section{City Attributes}

Perceived brand quality and brand uniqueness played crucial role in deciding effective brand position. Like a brand, for example, place also met functional needs, symbolic as well as emotion (Rainisto, 2003), and the attributes that bring benefits. These need should be integrated in to uniqueness of place offering (Kavaratzis, 2005). Many researchers have proposed related criteria by identifying which place quality is interesting for talents (Lloyd and Clark, 2001)). For example, (Rainisto, 2003) divided city attributes in to three criterions to explain the place development. Community service development should be able to offer qualified environment for citizens. This service development is related with welfare management, such as social facilities, health and education which contributed to the quality of social live. City planning and design focused on a quality place design such as architecture, street layouts as well as environmental quality.

City design is very important to increase the level perception of city security. The function of economic development is to provide the aids for a place to leverage its competitiveness. Economics development is related with working opportunities and international attitudes. A deeper study on city brand image (Merrilees et al., 2009) conducted and established the level of attributes community as follows: brand personality, security, business creativity, nature, shopping, social bonding, cultural activity and clean sanitation. Aligned with (Insch, 2010) identified the fundamental factors which contributed on citizen satisfaction, work/live balance, security, environment and city community assets. (Darchen and Tremblay, 2010) also identified the most affected criterion on attractiveness on university such as quality of university, working quality, life quality (social welfare, the level of safety, quality of city environment, public transportation quality), the life styles (the access to social and culture activity, the level of tolerance (several of ethnic and culture).

Meanwhile (Santos et al., 2007) explored the life quality by measuring health, housing, recreation, trading and services, environment, social service, mobility, sports, culture, education, city safety, urbanism, poverty and exclusion, social and civic behavior. García et al (2012) had suggested that the pleasant atmosphere, holistic image, social economics infrastructure, environmental and security, natural resources and culture. Due to some different city features used differently by three different authors, there are also three consideration needed to be discussed, firstly, marketing literature did not show a relative consensus on the importance of city attributes, secondly, it was found that only few studies determined the details of item structures from attribute and it led to understand how it measured. Thirdly, some authors referred to different attributes but they are comparable, the process of reclassification will be useful to combine the similar attributes. Current research had tried to summarize and re-rank the most critical city attributes based on its usage in empirical study regarding place attractiveness and brand attitude. The most cities attribute which are reported at most such as, urban design, culture activity and tourism. Urban study mostly explodes on the role of social capital, business creativity as well as job opportunities. Tourism study mainly focused on local and international transportation connectivity as well as environment sanity, meanwhile social study emphasized on safety, education, health and social services.

\section{HYPOTHESES DEVELOPMENT}

\section{The Relationship between Environmental Outlooks with City Attractiveness Performance}

Environmental outlook is closely related with climate change. It is found that the higher citizen's consciousness on health, the higher demand on friendly environment. The high rate demand on environment healthy requires more attention and all stakeholders mature decision to manage environment. Nowadays, climate change reminds us about ecological and ecosystem performance reduction. Cities, as well need to adapt to encounter the climate change challenges. The complexity existing in a city could be reflected in the various ecosystems. Many approaches and efforts have been implemented to evaluate city environmental climate for the sake of city looks performance for future, as well as how to sustain the environmental as one of city attributes (Mauree et al., 2019). The development of green building, energy consumption and land management also have a significant impact on a city attractiveness (de Munck and Lemonsu, 2018). It is believed that the indicators of green environment will affect city performance. Thus, this is to propose the following hypothesis.

H1: Environmental Outlook is expected to have a significant City Attribute on City Attractiveness Performance. 


\section{The Relationship between Social Services Responsiveness with City Attractiveness Performance.}

Some studies were conducted to find out how the speed services impacted interpersonal dimension (responsiveness, guarantee and empathy). Theoretically, it was estimated that when responsive services perceived by services users, it will lead to satisfaction. A study was conducted and identified three directions among human, building and public center services played crucial factors to customer's satisfaction (Hanks et al., 2017). Place attractiveness also considered as territorial attractiveness, regional attractiveness as well city attractiveness was conceptualized as positive key factors for a place. The capability of places to attract others for a destination is a basic consideration to increase trading competitiveness, services and industries. Attractiveness of place consists of three factors such as job opportunity, place bonding as well as life quality (Nguyen, 2020). This is to propose the following hypothesis.

H2: The Responsive Social Service is expected to have a significant City Attribute on City Attractiveness Performance

\section{The Relationship between Tourism and Cultural Heritage with CityAttractiveness Performance}

Attractiveness of cultural heritage is one of visitor's interests to visit a city. Cultural tourism destination introduced three drivers and highlighted the importance of cultural facility collections in a city, the impact of city attractiveness for visitors, residents and international tourism and local people appreciation on cultural heritage. Research finding stated that the importance of cultural heritage is significantly affecting the international visitors interest (Kourtit et al., 2019). Other studies investigated the attractiveness concept, place marketing and events through identity and image. Social, economics, tourism impact and place identity and image interaction could lead to long term attractiveness (Christophe and Boutard, 2017). City cultural is a basic nature which distinguished from other cities. The nature of cultural is the most basic of creative resources from city innovation. Culture is a powerful strength to push city nature form; a culture could also create inspiration, benefits and poverty that enhance the endless happiness. Strategic development of culture is becoming core strategic of cultural development. From the global cultural characteristics, other drivers increase city attractiveness (Wang et al., 2010). Thus, current study proposed the following hypothesis.

\section{H3: The Tourism and Cultural Heritage is expected to have a significant City Attribute on City Attractiveness Performance}

\section{The Relationship between Education and Job Opportunity with City Attractiveness Performance}

One of the city characters is educational city. Being popular with city of education triggered young to live and experience the life. The finding stated that the perception of graduated on a conducive work environment will possibly make them take a decision to stay. A good opportunity to have a job will lead to move and stay in a certain city. The perception on higher wages and salary was also noticed as other key factors (Nguyen, 2020). Other research finding claimed that physical attractiveness will directly affect the satisfaction through the trust and intellectual competency, from the satisfaction itself, it will affect the loyalty. The study also described that the direct relationship of physical attractiveness, intellectual competency on satisfaction and loyalty (Yeh et al., 2020). City of education and job opportunities in a city became a final destination of young talents as well as enrich city attractiveness. Thus, it is proposed the following hypothesis.

H4: The Education and Job Opportunity is expected to have a significant City Attribute on City Attractiveness Performance

\section{The Relationship between Safety and Health with City Attractiveness Performance}

Tourism activities are basically based on two parameters which are known as the interest to move and physical capability to conduct. The first parameter is considered from interest for place that inspires traveling aspiration, time availability as well as sufficient funding. Second parameter concerned on the capability to access the places visited through the transportation and information. All the factors mentioned above conclude as safety and health together with infrastructures development and tourism destination attractiveness will increase the city attractiveness (Ouariti and Jebrane, 2020). Research on tourism was started through social media. Social media also plays a crucial factor from the communication point of views. From the trusted social media, visitors could know the safety and security during traveling. The safety and security will also increase the city attractiveness (Pennington and Kaplanidou, 2012). This finding is also aligned with research conducted by (Mydin and Ayob, 2014). Thus, this is to propose the following hypothesis.

H5: Safety and Health are expected to have significant impact on city attractiveness performance

\section{The Relationship between International Levels with City Attractiveness Performance}

There are many different opinions among citizens that are still arguable about the indicators of a city as international level. Some citizens avoid the high mobility of a metropolitan city and tend to live in quite place, in another hands, the high mobility and so called the city never sleeps became final decision to live. These different opinion and experiences were absolutely related to their daily activities. Living in an international level of a city requires strict regulation and tough competition, and shifting behavior to more digital practices. Scientific studies have proven that law and human behavioral regulation tend more to digital information richness which is widely available. The big data available could enhance end user to use and reproduce the data. International level of a city could be known also from the provided and assessable information. To measure the city attractiveness could be done through three different aspects from three different activities bank card transaction, photos as well as tweet which is provided with geotag (Sobolevsky et al., 2015). The following hypothesis is proposed.

H6: The International Level is expected to have a significant city attribute on City Attribute on City Attractiveness Performance 


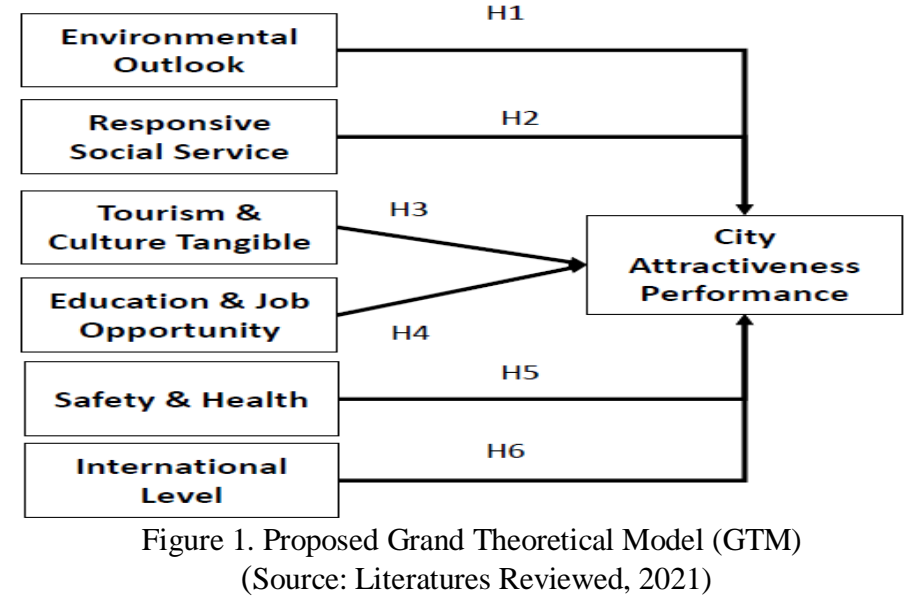

Having reviewed and discussed aforementioned literatures related for this study, the following proposed grand theoretical model (Figure 1) is summarized.

\section{RESEARCH METHODOLOGY}

Current research conducted in several cities (one province represent the 3rd part of Indonesia, Western, central and eastern) in Indonesia as option to live. As international tourism destination, this study was designed to find out the set of city attributes that are able to explain city capacity that interest talents to live. During this step, the data should be validated through Confirmatory Factor Analysis. Secondly, investigate the city attributes weather they could mirror the endogen variables in the structural equation modeling.

Table 1. Variable, Indicator and Definition (Source: Literatures reviewed, 2021)

\begin{tabular}{|c|c|c|c|}
\hline No & Variable & Indicators & Definition \\
\hline 1 & $\begin{array}{c}\text { Environmental } \\
\text { Outlook }\end{array}$ & $\begin{array}{l}\text { - Green areas availability } \\
\text { - Well ecological management } \\
\text { - Effective pollution management } \\
\text { - Environmentally housing developer } \\
\text { - Green public availability } \\
\end{array}$ & $\begin{array}{l}\text { The green performance of an urban which is defined } \\
\text { trough the availability of green areas, a well-managed } \\
\text { ecological, pollution, housing as well as the public } \\
\text { transportation (Smith et al., 2005) }\end{array}$ \\
\hline 2 & $\begin{array}{c}\text { Social Service } \\
\text { Responsiveness }\end{array}$ & $\begin{array}{l}\text { - Reachable and accessibility all social facilities } \\
\text { - Affordable job opportunities } \\
\text { - Availability of social welfare and security }\end{array}$ & $\begin{array}{l}\text { The speed response of a city regarding social service } \\
\text { provided which is known from reachable and easy } \\
\text { access to social facilities, the opportunity to seek job, } \\
\text { social welfare and security perceived (Zenker et al., 2013) }\end{array}$ \\
\hline 3 & $\begin{array}{c}\text { Tourism and } \\
\text { Culture } \\
\text { Tangible }\end{array}$ & $\begin{array}{l}\text { - Iconic urban performance } \\
\text { - Various cultural events advantage } \\
\text { - Well managed culture heritages } \\
\text { - Green cultural and tourism promotional advantage } \\
\text { - Expenditures advantage experience-based }\end{array}$ & $\begin{array}{l}\text { The evidence and reality existed in a city that offered } \\
\text { the iconic resources, various cultural events } \\
\text { advantage, a well-managed cultural sites heritages, } \\
\text { promotional advantage as well as value for money } \\
\text { (Barrère, 2016); (Adie, 2017) }\end{array}$ \\
\hline 4 & $\begin{array}{c}\text { Education and } \\
\text { Job } \\
\text { Opportunity }\end{array}$ & $\begin{array}{l}\text { - Availability of training centers } \\
\text { - Affordable of all facilities for educated graduates } \\
\text { - The existence of specialized human resources training. } \\
\text { - The availability of Soft Skill and Hard Skill Training Center } \\
\text { - The "link and match" between education and job } \\
\text { opportunities }\end{array}$ & $\begin{array}{l}\text { The link and match advantage between education and } \\
\text { job work opportunities that offers the availability of } \\
\text { training center and facilities for graduates, specialized } \\
\text { human resources training for soft and hard skill } \\
\text { (Jiang and } \mathrm{Li}, 2009 \text { ) }\end{array}$ \\
\hline 5 & $\begin{array}{l}\text { Safety and } \\
\text { Health }\end{array}$ & $\begin{array}{l}\text { - The availability of health center } \\
\text { - Ensure the safety and security } \\
\text { - Standardized of general food and beverages } \\
\text { - Secured feeling for modern public transportation }\end{array}$ & $\begin{array}{l}\text { The health and safety perceived through the } \\
\text { availability of health center, security ensured, a } \\
\text { trusted worthy food and beverages and a safe feeling } \\
\text { for modern transportation (García et al., 2012) }\end{array}$ \\
\hline 6 & $\begin{array}{c}\text { International } \\
\text { Level }\end{array}$ & $\begin{array}{l}\text { - Interconnected public transportation } \\
\text { - Green reputation of accommodation (Hotel, Cafe, Airport) } \\
\text { - Educated and welcome local residents } \\
\text { - Memorable journey and experience }\end{array}$ & $\begin{array}{l}\text { The nature of international of a city which has met some } \\
\text { indicators such interconnected public transportation, } \\
\text { green accommodation reputation, educated attitude and } \\
\text { welcome of local people as well as memorable } \\
\text { experiences (Gopalan and Narayan, 2010) }\end{array}$ \\
\hline 7 & \begin{tabular}{|c|} 
City \\
Attractiveness \\
Performance
\end{tabular} & $\begin{array}{l}\text { - High young productive workforces } \\
\text { - The Easiness to start business } \\
\text { - The high quality of education, health and entertainment } \\
\text { - The rapid growth of Industries and trading }\end{array}$ & $\begin{array}{l}\text { The attractiveness of city attributes perceived by } \\
\text { residents through productive workforces, business } \\
\text { establishment, high quality of education, high standard } \\
\text { of health, entertainment and the rapid growth of } \\
\text { industries and trading (Coelho and Bairrada, 2020) }\end{array}$ \\
\hline
\end{tabular}

\section{Data Collection Technique.}

Pre-survey was conducted on graduated students, job seeker or citizens who want to begin a life in a new city. Three provinces served as a home-based data collection, Medan as a province of North Sumatera with government program to increase the level of city, secondly Palangkaraya which is planned to be the Capital City of Indonesia and The eastern part of Indonesia presented by Bali Province. A non purposive sampling with purposive sampling technique was deployed with some criteria must be fulfilled by potential respondents with a survey was conducted with Google form. Data collection was conducted in 2020 for three months. Sampling measurement was of 600 respondents. The similar studies such as (Zenker et al., 2013) or study with a small sample (Zhang and Zhao, 2009). These studies exploited data base on potential residents to determine city attractiveness for talents.

\section{Structural Equation Modeling}

The proposed model was assessed by using Structural Equation Modeling approach. This modeling is a statistical tool as a mandatory to factor analysis and confirmatory factor analysis. The CFA model finding (Figure 2) with 
coefficient Cronbach alpha and other measurements. A full structural modeling above provided some information. A model considered a good model based on the consideration of some indicators and cut off value. By using structural equation modeling, the explanatory and CFA were tested. This model tested and analyzed the latent constructs and the interrelation of variables. The procedure of discriminant and convergent were deployed to analyze and measure the latent variables. To find out the validity measurement model was analyzed by a confirmatory factor analysis, meanwhile, the simultaneous equation modeling was tested to know the interrelation of all variables in a model.

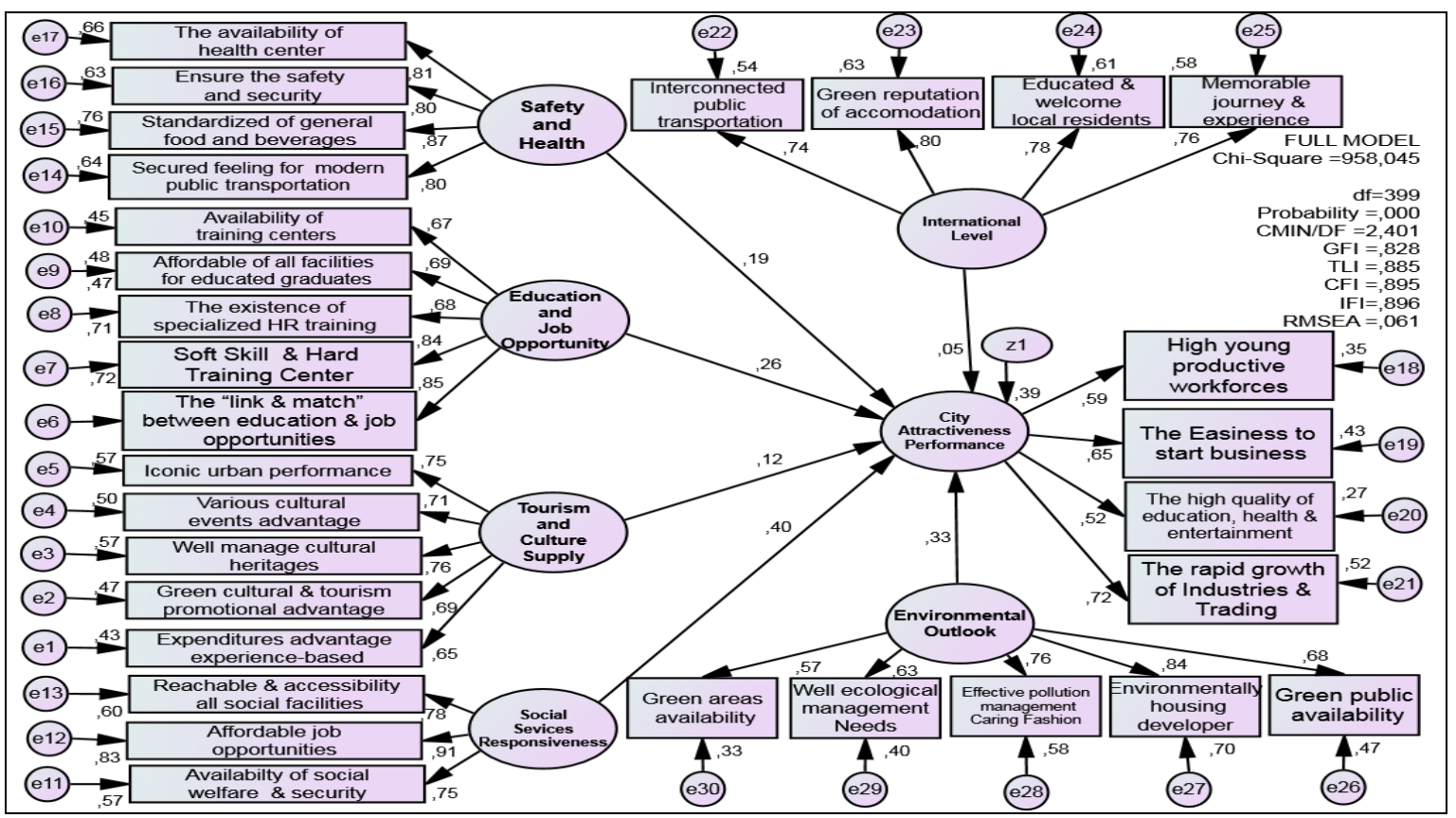

Figure 2. Full Structural Equation Modeling Source: Output SEM with AMOS (2021)

Table 2. Measurement Scales, Confirmatory Factor Analysis, and Reliability (Source: Output of SEM with Amos, 2021)

\begin{tabular}{|c|c|c|c|}
\hline No & Variable & Indicators & ion \\
\hline 1 & $\begin{array}{c}\text { Environmental } \\
\text { Outlook }\end{array}$ & $\begin{array}{l}\text { - Green areas availability } \\
\text { - Well ecological management } \\
\text { - Effective pollution management } \\
\text { - Environmentally housing developer } \\
\text { - Green public availability }\end{array}$ & $\begin{array}{l}\text { The green performance of an urban which is defined } \\
\text { trough the availability of green areas, a well-managed } \\
\text { ecological, pollution, housing as well as the public } \\
\text { transportation (Smith, Glasson, \& Chadwick, 2005) }\end{array}$ \\
\hline 2 & $\begin{array}{c}\text { Social Service } \\
\text { Responsiveness }\end{array}$ & $\begin{array}{l}\text { - Reachable \& accessibility all social facilities } \\
\text { - Affordable job opportunities } \\
\text { - Availability of social welfare \& security }\end{array}$ & $\begin{array}{l}\text { The speed response of a city regarding social service } \\
\text { provided which is known from reachable and easy } \\
\text { access to social facilities, the opportunity to seek job, } \\
\text { social welfare and security perceived (Zenker, } \\
\text { Petersen, \& Aholt, 2013) }\end{array}$ \\
\hline 3 & $\begin{array}{c}\text { Tourism \& } \\
\text { Culture } \\
\text { Tangible }\end{array}$ & $\begin{array}{l}\text { - Iconic urban performance } \\
\text { - Various cultural events advantage } \\
\text { - Well managed culture heritages } \\
\text { - Green cultural \& tourism promotional advantage } \\
\text { - Expenditures advantage experience-based }\end{array}$ & $\begin{array}{l}\text { The evidence and reality existed in a city that offered } \\
\text { the iconic resources, various cultural events } \\
\text { advantage, a well-managed cultural sites heritages, } \\
\text { promotional advantage as well as value for money } \\
\text { (Barrère, 2016); (Adie, 2017) }\end{array}$ \\
\hline 4 & $\begin{array}{c}\text { Education \& } \\
\text { Job } \\
\text { Opportunity }\end{array}$ & $\begin{array}{l}\text { - Availability of training centers } \\
\text { - Affordable of all facilities for educated graduates } \\
\text { - The existence of specialized human resources training. } \\
\text { - The availability of Soft Skill and Hard Skill Training Center } \\
\text { - The "link \& match" between education and job opportunities }\end{array}$ & $\begin{array}{l}\text { The link and match advantage between education and } \\
\text { job work opportunities that offers the availability of } \\
\text { training center and facilities for graduates, specialized } \\
\text { human resources training for soft and hard skill } \\
\text { (Jiang \& Li, 2009) }\end{array}$ \\
\hline 5 & $\begin{array}{c}\text { Safety \& } \\
\text { Health }\end{array}$ & $\begin{array}{l}\text { - The availability of health center } \\
\text { - Ensure the safety and security } \\
\text { - Standardized of general food and beverages } \\
\text { - Secured feeling for modern public transportation }\end{array}$ & $\begin{array}{l}\text { The health and safety perceived through the } \\
\text { availability of health center, security ensured, a } \\
\text { trusted worthy food and beverages and a safe feeling } \\
\text { for modern transportation (García et al., 2012) }\end{array}$ \\
\hline 6 & $\begin{array}{c}\text { International } \\
\text { Level }\end{array}$ & $\begin{array}{l}\text { - Interconnected public transportation } \\
\text { - Green reputation of accommodation (Hotel, Cafe, Airport) } \\
\text { - Educated \& welcome local residents } \\
\text { - Memorable journey \& experience }\end{array}$ & $\begin{array}{l}\text { The nature of international of a city which has met } \\
\text { some indicators such interconnected public } \\
\text { transportation, green accommodation reputation, } \\
\text { educated attitude and welcome of local people as well } \\
\text { as memorable experiences (Gopalan \& Narayan, 2010) }\end{array}$ \\
\hline 7 & \begin{tabular}{|c|} 
City \\
Attractiveness \\
Performance
\end{tabular} & $\begin{array}{l}\text { - High young productive workforces } \\
\text { - The Easiness to start business } \\
\text { - The high quality of education, health \& entertainment } \\
\text { - The rapid growth of Industries \& trading }\end{array}$ & $\begin{array}{l}\text { The attractiveness of city attributes perceived by } \\
\text { residents through productive workforces, business } \\
\text { establishment, high quality of education, high standard } \\
\text { of health, entertainment and the rapid growth of } \\
\text { industries and trading (Coelho \& Bairrada, 2020) }\end{array}$ \\
\hline
\end{tabular}


Statistical outputs for CFA presented above, highlighted that coefficient Cronbach Alpha more than 0.6 to claim the good reliability each constructs (Nunnally, 1978). Average Variance Extracted (AVE) also showed good measurement to enhance validity of convergent model to be evaluated. Other indicators presented in table also showed the significant indicator such alpha and CR. Table 2 provided the Standardized Loading $(\lambda)$ from each variable. The highest loading factor from environmental outlook is environmentally housing developer (0. 84). It means, the respondents prefer the good housing developer. Affordable job opportunities have the higher loading factor (0.91) from responsive social service. The highest reliability belongs to the iconic urban performance ( 0.75$)$ (tourism and culture tangible).

Convergent reliability of the link and match between education and job opportunities is 0.85 of education and job opportunities. The highest loading factor from safety and health is standardized of general food and beverages (0. 87). Meanwhile, the green reputation of accommodation and the easiness to start a business are $(0.80$ and 0.70$)$ respectively from the variable of international level and city attractiveness performance. For more detail (Table 2).

Goodness of fit model was determined through some indexes. The GoF such as AGFI, GFI, NFI and RFI some meet the rule of thumb or cut of value some others meet the marginal fits, RMSEA also showed fit index under 0.08 (Table 3 ). This is to conclude that, generally the model is considered parsimony.

Table 3. Absolute, Incremental, Parsimony Fit

Measurements (Source: Output SEM with AMOS, 2021)

\begin{tabular}{|c|c|}
\hline $\begin{array}{c}\text { INDICATORS OF } \\
\text { ABSOLUTE FIT MEASUREMENT }\end{array}$ & \\
\hline $\begin{array}{l}\text { - CMIN/DF (The Minimum Sample Discrepancy } \\
\text { Function Divide With Degree of Freedom) }\end{array}$ & 958.045 \\
\hline - RMSEA (Root Mean Square Error Approximation) & 0.061 \\
\hline - GFI (Goodness of Fit Index) & 0.826 \\
\hline - Chi-squared $\left(\chi^{2}\right)$ & 2401 \\
\hline - $\mathrm{P}($ probability) & 0.000 \\
\hline $\begin{array}{c}\text { INDICATORS OF } \\
\text { INCREMENTAL FIT MEASUREMENT }\end{array}$ & \\
\hline - AGFI (Adjusted Goodness of Fit Index) & 0.908 \\
\hline - TLI (Tucker Lewis Index) & 0.880 \\
\hline - NFI & 0.830 \\
\hline - CFI (Comparative Fit Index) & 0,897 \\
\hline $\begin{array}{c}\text { INDICATORS OF } \\
\text { PARSIMONY FIT MEASUREMENT }\end{array}$ & \\
\hline - PNFI (Parsimonious Normal Fit Index) & 0.80 \\
\hline - PGFI (Parsimonious Goodness-of Fit Index) & 0.81 \\
\hline - Hoelter $(0,01)$ & 187 \\
\hline
\end{tabular}

Table 4. Regression Weights (Source: Output SEM with AMOS, 2021)

\begin{tabular}{|c|c|c|c|c|c|c|c|c|}
\hline \multicolumn{3}{|c|}{ Hypotheses } & Est. & S.E. & C.R. & $\mathrm{P}$ & Label & $\mathrm{H}$ \\
\hline $\begin{array}{l}\text { City } \\
\text { Attractiveness } \\
\text { Performance }\end{array}$ & - & $\begin{array}{l}\text { Environmental } \\
\text { Outlook }\end{array}$ & .217 & .042 & 5.100 & $* * *$ & par_24 & Accepted \\
\hline $\begin{array}{l}\text { City } \\
\text { Attractiveness } \\
\text { Performance }\end{array}$ & <- & $\begin{array}{l}\text { Safety and } \\
\text { Health }\end{array}$ & .115 & .034 & 3.346 & $* * *$ & par_25 & Accepted \\
\hline $\begin{array}{l}\text { City } \\
\text { Attractiveness } \\
\text { Performance } \\
\end{array}$ & <- & \begin{tabular}{|l|} 
Education \\
and Job \\
Opportunity \\
\end{tabular} & 142 & .032 & 4.414 & $* * *$ & par_26 & Accepted \\
\hline $\begin{array}{l}\text { City } \\
\text { Attractiveness } \\
\text { Performance } \\
\end{array}$ & & $\begin{array}{l}\text { International } \\
\text { Level }\end{array}$ & .026 & .032 & .807 & .420 & par_27 & Rejected \\
\hline $\begin{array}{l}\text { City } \\
\text { Attractiveness } \\
\text { Performance }\end{array}$ & & $\begin{array}{l}\text { Social Services } \\
\text { Responsiveness }\end{array}$ & .229 & $\mid .037$ & 6.122 & $* * *$ & par_28 & Accepted \\
\hline $\begin{array}{l}\text { City } \\
\text { Attractiveness } \\
\text { Performance }\end{array}$ & & $\begin{array}{l}\text { Tourism and } \\
\text { Culture } \\
\text { Supply }\end{array}$ & .085 & .042 & 2.046 &, 041 & par_29 & Accepted \\
\hline
\end{tabular}

\section{Research Findings}

As mentioned previously, the purpose of current study is to evaluate the antecedent's city attractiveness to attract the potential residents and talents to choose and live in a city. Table 4 above highlighted regression weights of all hypotheses proposed. The highest CR as antecedent of city attractiveness is social services responsiveness. This is to claim that, potential resident and talents considered social services as the most important factor to consider if they want to live in a city (CR: 6.122). The second consideration is the environmental outlook. The environmentally friendly became the second consideration to live in a city (CR: 5.100). While the education and job opportunity comes in the third place (CR 4.414). While the stay and health, tourism and culture supply in the fourth and fifth respectively (CR 3.346 and 2.046). All the respondents agreed that the international level of a city is not the factor to consider as the impact of international level is insignificant on city attractiveness (CR: 0.807).

\section{DISCUSSION}

\section{Implication for City Branding}

City as the destination is a complex construct where the place marketing should be able to provide a satisfaction for all different stakeholders needs to increase the reputation of city brand, competitiveness and attractiveness. This study involved the potential residents and talents to choose the city to live in a city as their final place to live. Many previous research analyzed the perception and involvement of residents (Braun and Kalandides, 2013), but fewer authors were interested to focus on city attractiveness in order to attract the talents, which is commonly generalized for national and international talents (Darchen and Tremblay, 2010). Statistical outputs demonstrated that the related criterion of place quality has different impacts on the attractiveness. Some of city attractiveness such as, educational quality, social and health services, international level, cultural and tourism attractiveness, environmental look are becoming key drivers when a city is evaluated as a place that could attract workers, businessman and talents.

On the other hand, the factors of international level are insignificant. Social and health responsiveness is becoming the most important indicators that respondent considered, this variable is measured by the reachable and accessibility of all social facilities (transportation, health center, entertainment), affordable or availability of job opportunities as well as the availability of social welfare and security. The environmental outlook played a second important role to increase the city attractiveness. All the respondent really cared and concerned about Green areas, well ecological management 
Effective pollution management, environmentally housing developer and Green public availability. The existence of good education and job opportunity also dragged respondent attention. It has been proven by its indicators that enhances its attractiveness through Availability of training centers, Affordable of all facilities for educated graduates, the existence of specialized human resources training, the availability of Soft Skill and Hard Skill Training Center and the "link and match" between education and job opportunities.

The attractiveness of health and safety came in the fourth place. Compared with the others variable, these indicators of health and safety did not attract respondent's attention as a consideration to choose a city to live. This variable is measured with the availability of health center, ensures the safety and security, standardized of general food and beverages and secured feeling for modern public transportation. Culture and tourism have a positive impact to enhance city attractiveness. This, probably when city has Iconic urban performance, Various cultural events advantage, well managed cultural heritages, Green cultural and tourism promotional advantage and Expenditures advantage experience-based or value of money. Unfortunately, the finding of current research, the international level has been showing the insignificant impact to enhance the city attribute attractiveness. Most of the respondents agree that the indicators of international level (Interconnected public transportation, Green reputation of accommodation (Hotel, Cafe, and Airport), Educated and welcome local residents and memorable journey and experience) are not the priority for them to live.

\section{Implication for Place Marketing}

In accordance with regression weights, the most key determinant factors for city attribute attractiveness are social services responsiveness and environmental outlook. The existence of well social services has become a consideration made by potential residents and talents once they start to be a permanent resident in certain city. Compared with the education and job opportunity in a third place, if the first three categories well blended together, they are going to be effective to enhance city attribute attractiveness. The well-educated residents and talents would be firmly to decide to live in. The infrastructures of social services, environmental friendly and the education center will fulfill their basic needs.

\section{CONCLUSION}

Because the brand association is different from various targeted groups, place planning and strategic communication requires detailed and constant analysis regarding the interested and perception of stakeholders. Since this study is engaged with high educated persons and talents, so they are expected to make a decision to be generalized and as a base to take decision. The most three emerging findings for current study, social service, environmental friendly and education center have been playing crucial impact on city attributes. The character of the international level of city, somehow, has been approved insignificant to increase city attribute attractiveness.

\section{Research Limitation and Further Research}

To estimate empirical evidence, some research limitations are worth to put into consideration. Firstly, frequently asked question in quantitative research is always around about the quality of respondent surveyed. To minimize this question, early in research methodology, sampling technique, the respondents were screened through sampling method, non-probability sampling technique with purposive sampling. Besides, current research extended previous research concerned on city attribute (Zenker et al., 2013). Further research would like to add others attributes such as city size, the existence of religion services and tolerance aspect.

\section{REFERENCES}

Adie, B.A. (2017). Franchising our heritage: The UNESCO World Heritage brand. Tourism Management Perspectives, $24,48-53$. https://doi.org/ 10.1016/j.tmp.2017.07.002

Ahn, Y.J., Hyun, S.S., \& Kim, I. (2015). City Residents' Perception of MICE City Brand Orientation and Their Brand Citizenship Behavior: A Case Study of Busan, South Korea. Asia Pacific Journal of Tourism Research, 21(3), 328-353. https://doi.org/ $10.1080 / 10941665.2015 .1050422$

Ansary, A., \& Nik Hashim, N.M.H. (2017). Brand image and equity: the mediating role of brand equity drivers and moderating effects of product type and word of mouth. Review of Managerial Science, 12(4), 969-1002. https://doi.org/ 10.1007/s11846-017-0235-2

Anusorntharangkul, N., \& Rugwongwan, Y. (2021). Using Inquiry-Based Learning to Explore Respect of Cultural Base Design: A Case Study in Amphawa Tourism Community, Thailand. GeoJournal of Tourism and Geosites, 34(1), 164-169. https://doi.org/: 10.30892/gtg.34121-632

Ashworth, G., \& Kavaratzis, M. (2007). Beyond the logo: Brand management for cities. Journal of Brand Management, 16(8), $520-531$. https://doi.org/ 10.1057/palgrave.bm.2550133

Atilgan, E., Aksoy, Ş., \& Akinci, S. (2005). Determinants of the brand equity. Marketing Intelligence and Planning, 23(3), $237-248$. https://doi.org/ 10.1108/02634500510597283

Barrère, C. (2016). Cultural heritages: From official to informal. City, Culture and Society, 7(2), 87-94. https://doi.org/10. 1016/j.ccs.2015.11.004

Bose, S., Roy, S.K., \& Tiwari, A.K. (2016). Measuring customer-based place brand equity (CBPBE): an investment attractiveness perspective. Journal of Strategic Marketing, 24(7), 617-634. https://doi.org/10.1080/0965254x.2016.1148766

Braun, E., \& Kalandides, A. (2013). My city - my brand: the different roles of residents in place branding. Journal of Place Management and Development, 6(1), 18-28. https://doi.org/ 10.1108/17538331311306087

Chaulagain, S., Wiitala, J., \& Fu, X. (2019). The impact of country image and destination image on US tourists' travel intention. Journal of Destination Marketing and Management, 12, 1-11. https://doi.org/ 10.1016/j.jdmm.2019.01.005

Chen, C.F., \& Chen, F.S. (2010). Experience quality, perceived value, satisfaction and behavioral intentions for heritage tourists. Tourism Management, 31(1), 29-35. https://doi.org/ 10.1016/j.tourman.2009.02.008 
Cheng, C.K., \& Kuo, H.Y. (2015). Bonding to a new place never visited: Exploring the relationship between landscape elements and place bonding. Tourism Management, 46, 546-560. https://doi.org/10.1016/j.tourman.2014.08.006

Chi, C.G.Q., Cai, R., \& Li, Y. (2017). Factors influencing residents' subjective well-being at World Heritage Sites. Tourism Management, 63, 209-222. https://doi.org/ 10.1016/j.tourman.2017.06.019

Christophe Alaux, \& Boutard, L. (2017). Place Attractiveness and Events: From Economic Impacts to Place Marketing Journal of International Business Research and Marketing, 2(4). https://doi.org/10.18775/jibrm.18498558.2015.24.3004

Coelho, A., \& Bairrada, C. (2020). The Drivers of the City Brand Equity Comparing Citizens' and Tourists' Perceptions and Its Influence on the City Attractiveness: The Case of the City of Coimbra. International Journal of Hospitality and Tourism Administration, 1-27. https://doi.org/ 10.1080/15256480.2020.1746215

Cortright, J., \& Coletta, C. (2006). The young and the restless: How Atlanta competes for talent. Atlanta, GA: Metro Atlanta Chamber of Commerce.

Darchen, S., \& Tremblay, D.G. (2010). What attracts and retains knowledge workers/students: The quality of place or career opportunities? The cases of Montreal and Ottawa. Cities, 27(4), 225-233. https://doi.org/ 10.1016/j.cities.2009.12.009

De Carlo, M., \& Canali, S. (2009). Moving Milan towards Expo 2015: designing culture into a city brand. Journal of Place Management and Development, 2(1), 8-22. https://doi.org/ 10.1108/17538330910942762

De Man, A. (2020). Advances in Cultural Tourism: Two Examples from the Emirate of Abu Dhabi (Uae). GeoJournal of Tourism and Geosites, 31(3), 1027-1033. https://doi.org/ 10.30892/gtg.31314-537

de Munck, C., \& Lemonsu, A. (2018). Evaluating the impacts of greening scenarios on thermal comfort and energy and water consumptions for adapting Paris city to climate change. Urban Climate, 23, 260-286. https://doi.org/ 10.1016/j.uclim.2017.01.003

De Noni, I., \& Orsi, L. (2014). Attributes of Milan influencing city brand attractiveness. Journal of Destination Marketing and Management, 3(4), 218-226. https://doi.org/ 10.1016/j.jdmm.2014.06.001

Escobar, D.A., \& Cardona, S. (2020). Accessibility as a Coverage Benefit Analysis Tool That an Airport Can Provide to a Region. Case Study: Colombian Coffee Cultural Landscape. GeoJournal of Tourism and Geosites, 31(3), 1092-1102. https://doi.org/ $10.30892 /$ gtg. $31322-545$

Farida, N., \& Ardyan, E. (2016). Attribute Attractiveness of City, City Brand Love and Tourist Behavior: the Case of Jakarta. https://doi.org/ 10.2991/icpm-16.2016.26

Fetscherin, M., \& Dinnie, K. (2010). The determinants and measurement of a country brand: the country brand strength index. International Marketing Review, 27(4), 466-479. https://doi.org/ 10.1108/02651331011058617

Fiocca, R., \& Gavinelli, L. (2011). Dimensioni di attrattivitÀ della cittÀ e implicazioni di marketing. Una ricerca sulle percezioni dei potenziali cittadini. Mercati and CompetitivitÀ(3), 39-63. https://doi.org/10.3280/mc2011-003004

Fitchett, J.A. (2005). Consumers as stakeholders: Prospects for democracy in marketing theory. Business Ethics: A European Review, 14(1), 14-27. https://doi.org/ 10.1111/j.14678608.2005.00383.x

Florida, R. (2008). Who's Your City: How the Creative Economy is Making Where to Live the Most Important Decision of Your Life. New York: Basic Books.

García, J.A., Gómez, M., \& Molina, A. (2012). A destination-branding model: An empirical analysis based on stakeholders. Tourism Management, 33(3), 646-661. https://doi.org/ 10.1016/j.tourman.2011.07.006

Garrod, B., \& Fyall, A. (2012). Engaging residents as stakeholders of the visitor attraction. Tourism Management, 33(5), $1159-1173$. https://doi.org/ 10.1016/j.tourman.2011.11.014

Gatrell, J., Reid, N., \& Steiger, T.L. (2018). Branding spaces: Place, region, sustainability and the American craft beer industry. Applied Geography, 90, 360-370. https://doi.org/ 10.1016/j.apgeog.2017.02.012

Godey, B., Manthiou, A., Pederzoli, D., Rokka, J., Aiello, G., Donvito, R., \& Singh, R. (2016). Social media marketing efforts of luxury brands: Influence on brand equity and consumer behavior. Journal of Business Research, 69(12), 5833-5841. https://doi.org/10.1016/j.jbusres.2016.04.181

Gómez, M., Lopez, C., \& Molina, A. (2015). A model of tourism destination brand equity: The case of wine tourism destinations in Spain. Tourism Management, 51, 210-222. https://doi.org/10.1016/j.tourman.2015.05.019

Gopalan, R., \& Narayan, B. (2010). Improving customer experience in tourism: A framework for stakeholder collaboration. SocioEconomic Planning Sciences, 44(2), 100-112. https://doi.org/ 10.1016/j.seps.2009.11.001

Gorochnaya, V., and Mikhaylov, A. (2021). The Interdependence between Tourism and Innovation Activity in the Western Borderlands of Russia. GeoJournal of Tourism and Geosites, 34(1), 147-154. https://doi.org/ 10.30892/gtg.34119-630

Hanks, L., Line, N., \& Kim, W.G. (2017). The impact of the social servicescape, density, and restaurant type on perceptions of interpersonal service quality. International Journal of Hospitality Management, 61, 35-44. https://doi.org/ 10.1016/j.ijhm.2016.10.009

Herrero, Á., \& San Martín, H. (2017). Examining the hierarchy of destination brands and the chain of effects between brand equity dimensions. Journal of Destination Marketing and Management, 6(4), 353-362. https://doi.org/ 10.1016/j.jdmm.2016.05.001

Hildreth, J. (2011). The Saffron European city brand barometer (Report). Retrieved from Saffron Brand Consultants. Saffron Brand Consultants.

Hultman, M., Skarmeas, D., \& Oghazi, P. (2015). Achieving tourist loyalty through destination personality, satisfaction, and identification. Journal of Business Research, 68(11), 2227-2231. https://doi.org/10.1016/j.jbusres.2015.06.002

Ilieș, D.C., Caciora, T., Herman, G.V., Ilieș, A., Ropa, M., \& Baias, Ş. (2020). Geohazards Affecting Cultural Heritage Monuments.A Complex Case Study from Romania. GeoJournal of Tourism and Geosites, 31(3), 1103-1112. https://doi.org/ 10.30892/gtg.31323-546

Iniesta-Bonillo, M.A., \& Sánchez-Fernández, R. (2016). Sustainability, value, and satisfaction: Model testing and cross-validation in tourist destinations. Journal of Business Research, 69(11), 5002-5007. https://doi.org/10.1016/j.jbusres.2016.04.071

Insch, A. (2010). Managing residents' satisfaction with city life: Application of importance-satisfaction analysis. Journal of Town and City Management, 1(2), 164-174.

Istiqomah, \& Adawiyah, W.R. (2020). Promoting Local Potential as a Strategy to Develop Tourism Village. GeoJournal of Tourism and Geosites, 31(3), 1113-1118. https://doi.org/10.30892/gtg.31324-547

Jiang, X., \& Li, Y. (2009). An empirical investigation of knowledge management and innovative performance: The case of alliances. Research Policy, 38(2), 358-368. https://doi.org/10.1016/j.respol.2008.11.002

Kani, Y., \& Aziz, Y.A. (2017). Antecedents and outcomes of destination image of Malaysia. Journal of Hospitality and Tourism Management, 32, 89-98. https://doi.org/ 10.1016/j.jhtm.2017.05.001

Kavaratzis, M. (2005). Place Branding: A Review of Trends and Conceptual Models. The Marketing Review, 5(4), $329-342$. https://doi.org/ 10.1362/146934705775186854 
Kavaratzis, M., \& Ashworth, G.J. (2006). City branding: An effective assertion of identity or a transitory marketing trick? Place Branding, 2(3), 183-194. https://doi.org/10.1057/palgrave.pb.5990056

Kavaratzis, M., \& Hatch, M.J. (2013). The dynamics of place brands. Marketing Theory, 13(1), 69-86. https://doi.org/ $10.1177 / 1470593112467268$

Kladou, S., \& Kehagias, J. (2014). Assessing destination brand equity: An integrated approach. Journal of Destination Marketing and Management, 3(1), 2-10. https://doi.org/10.1016/j.jdmm.2013.11.002

Kotler, P., \& Bowen, J. (2003). Marketing delturismo (trad.It). Milano: McGraw-Hill.

Kourtit, Nijkamp, \& Romão. (2019). Cultural Heritage Appraisal by Visitors to Global Cities: The Use of Social Media and Urban Analytics in Urban Buzz Research. Sustainability, 11(12), 3470. https://doi.org/0.3390/su11123470

Lawton Smith, H., \& Glasson, J. (2005). The geography of talent: entrepreneurship and local economic development in Oxfordshire. Entrepreneurship and Regional Development, 17(6), 449-478. https://doi.org/ 10.1080/08985620500247819

Lloyd, R., \& Clark, T.N. (2001). The city as an entertainment machine. 6, 357-378. https://doi.org/ 10.1016/s1047-0042(01)80014-3

Markusen, A. (2004). Targeting Occupations in Regional and Community Economic Development. Journal of the American Planning Association, 70(3), 253-268. https://doi.org/10.1080/01944360408976377

Mauree, D., Naboni, E., Coccolo, S., Perera, A.T.D., Nik, V.M., \& Scartezzini, J.L. (2019). A review of assessment methods for the urban environment and its energy sustainability to guarantee climate adaptation of future cities. Renewable and Sustainable Energy Reviews, 112, 733-746. https://doi.org/10.1016/j.rser.2019.06.005

Merrilees, B., \& Abimbola, T. (2012). Multiple stakeholders and multiple city brand meanings. European Journal of Marketing, 46(7/8), 1032-1047. https://doi.org/10.1108/03090561211230188

Merrilees, B., Miller, D., \& Herington, C. (2009). Antecedents of residents' city brand attitudes. Journal of Business Research, 62(3), 362-367. https://doi.org/ 10.1016/j.jbusres.2008.05.011

Michaels, E., \& Handfield-Jones, H. (2001). The war for talent. Boston, MA: Harvard Business Press.

Miftahuddin, A., \& Hermanto, B. (2021). City Branding and Its Variables: The Evidence from Indonesia. GeoJournal of Tourism and Geosites, 34(1), 240-244. https://doi.org/10.30892/gtg.34132-643

Nguyen, T.T. (2020). The Impact of Place Attractiveness and Social Supports on Internal Return Migration. The Journal of Asian Finance, Economics and Business, 7(5), 305-314. https://doi.org/ 10.13106/jafeb.2020.vol7.no5.305

Othuman Mydin, M.A., \& Mohd Ayob, N. (2014). Issues of Safety and Security: New Challenging to Malaysia Tourism Industry. SHS Web of Conferences, 12, 01083. https://doi.org/10.1051/shsconf/20141201083

Ouariti, O.Z., \& Jebrane, E.M. (2020). The impact of transport infrastructure on tourism destination attractiveness: A case study of Marrakesh City, Morocco. African Journal of Hospitality, Tourism and Leisure, 9(2), 2-19. http//:www.ajhtl.com.

Pennington-Gray, L., \& Kaplanidou, K. (2012). Drivers of social media use among African Americans in the event of a crisis. Natural Hazards, 66(1), 77-95. https://doi.org/ 10.1007/s11069-012-0101-0

Porter, M.E. (2011). The competitive advantage of the inner city Stout(Eds.). New York: Routledge, 5, 282-295.

Rainisto, S.K. (2003). Success factors of place marketing: A study of place marketing practices in Northern Europe and the United States. Doctoral Dissertations.

Santos, L.D., Martins, I., \& Brito, P. (2007). Measuring Subjective Quality of Life: A Survey to Porto's Residents. Applied Research in Quality of Life, 2(1), 51-64. https://doi.org/ 10.1007/s11482-007-9029-Z

Smith, L.H., Glasson, J., \& Chadwick, A. (2005). The geography of talent: Entrepreneurship and local economic development in Oxford shire. An International Journal of Entrepreneurship and Regional Development, 17(6), 449-478.

Sobolevsky, S., Bojic, I., Belyi, A., Sitko, I., Hawelka, B., Arias, J.M., \& Ratti, C. (2015). Scaling of City Attractiveness for Foreign Visitors through Big Data of Human Economical and Social Media Activity. 600-607. https://doi.org/ 10.1109/BigDataCongress.2015.92

Szente, V., \& Osiako, P.O. (2021). Community Based Ecotourism in Hungary: Citizens' Perceptions Towards the Roma Community. GeoJournal of Tourism and Geosites, 34(1), 233-239. https://doi.org/ 10.30892/gtg.34131-642

Wang, D., Yang, J., \& Pei, H. (2010). The impact of global cities' cultural facilitiesand\#x2014;Inspiration for Shenzhen. 1-5. https://doi.org/10.1109/infra.2010.5679213

Wibowo, T.W., \& Santosa. (2021). Revealing Tourist Hotspots in Yogyakarta City Based on Social Media Data Clustering. GeoJournal of Tourism and Geosites, 34(1), 218-225. https://doi.org/ 10.30892/gtg.34129-640

Yeh, W.C., Lee, C.C., Yu, C., Wu, P.S., Chang, J.Y., \& Huang, J.H. (2020). The Impact of the Physical Attractiveness and Intellectual Competence on Loyalty. Sustainability, 12(10), 3970. https://doi.org/ 10.3390/su12103970

Yusuf, S., \& Nabeshima, K. (2005). Creative industries in East Asia. Cities, 22(2), 109-122. https://doi.org/ 10.1016/j.cities.2005.01.001

Zenker, \& Knubben, E. (2019). Yourcity, mycity, theircity, our city different perceptions of place brands by Diverse Target Groups. Paper presented at the 6th international conference thought leaders in brand management, Lugano, Switzerland.

Zenker, S., \& Kalandides, A. (2009). Who's your target? The creative class as a target group for place branding. Journal of Place Management and Development, 2(1), 23-32. https://doi.org/ 10.1108/17538330910942771

Zenker, S., Petersen, S., \& Aholt, A. (2013). The Citizen Satisfaction Index (CSI): Evidence for a four basic factor model in a German sample. Cities, 31, 156-164. https://doi.org/ 10.1016/j.cities.2012.02.006

Zeugner Roth, K.P., \& Diamantopoulos, A. (2008). Home Country Image, Country Brand Equity and Consumers' Product Preferences: An Empirical Study. Management International Review, 48(5), 577-602. https://doi.org/ 10.1007/s11575-008-0031-y

Zhang, L., \& Zhao, S.X. (2009). City branding and the Olympic effect: A case study of Beijing. Cities, 26(5), $245-254$. https://doi.org/10.1016/j.cities.2009.05.002

Zhang, B., \& Liu, L. (2014). Recognizing City Identity via Attribute Analysis of Geo-tagged Images. 8691, 519-534. https://doi.org/ 10.1007/978-3-319-10578-9_34

Article history: Received: 12.06.2021 Revised: 06.10.2021 Accepted: 24.11.2021 Available online: 17.12.2021 